\title{
Inter and intraindividual variations in plasma cholinesterase activity and substance concentration in employees of an organophosphorus insecticide
} factory

\author{
A Brock
}

\begin{abstract}
During a period of 10 months, inter and intraindividual variations in plasma cholinesterase (ChE) activity were studied in 331 employees of an organophosphorus insecticide factory, and in 193 healthy volunteers without occupational exposure to known $\mathrm{ChE}$ inhibitors. Repeated $(n=6)$ measurements of ChE activity and $\mathrm{ChE}$ substance concentration were performed in 410 subjects. The study showed substantial intraindividual variations of $\mathrm{ChE}$ activity and $\mathrm{ChE}$ substance concentration (up to $40 \%$ ) in the employees and in the reference group. When effects due to sex, ChE-1 phenotype, body weight, and height were considered, one subgroup of employees of the organophosphorus insecticide factory showed a significantly lower average $\mathrm{ChE}$ activity than other subgroups; as ChE substance concentrations were found to be proportionally decreased, it was concluded that the low ChE activity was unrelated to occupational exposure. A combined determination of $\mathrm{ChE}$ activity and ChE substance concentration is recommended as a rational diagnostic tool when an unexpected decrease of plasma ChE activity is registered in people joining organophosphorus insecticide health surveillance programmes.
\end{abstract}

Organophosphorus insecticides are highly toxic substances to man as well as to pests. Persons with risk for substantial occupational exposure to such substances are employees of organophosphorus insecticide factories and pesticide operators within gar-

University of Aarhus, Department of Clinical Chemistry, Randers Central Hospital, DK 8900 Randers, Denmark

A Brock dening and agriculture. Because even a few mg may possess appreciable toxic effects in man, and as absorbed organophosphorus insecticides are excreted as non-specific metabolites (for example, pnitrophenol from parathion and methyl-parathion), most programmes for health surveillance are based on measurements of plasma cholinesterase activity (ChE, pseudocholinesterase, butyrylcholinesterase, acylcholine acylhydrolase, EC 3.1.1.8), which is strongly inhibited by all organophosphorus insecticides. ${ }^{1}$ In such health surveillance programmes (as in other areas of clinical medicine) decisions should be made from rational interpretations of observed variations based on knowledge of spontaneous inter and intraindividual variations in the population. ${ }^{2}$

Biosynthesis of the 574 amino acid ChE subunit is controlled by the ChE-1 locus on chromosome No 3, where a number of alleles $\left(\mathrm{ChE}^{u}, \mathrm{ChE}^{\mathrm{a}}, \mathrm{ChE}^{f}, \mathrm{ChE}^{\mathrm{s}}\right.$, $\left.\mathrm{ChE}^{j}, \mathrm{ChE}^{\mathrm{k}}\right)$ define the actual genotype ${ }^{4}$; the genotype $\mathrm{ChE}^{u} \mathrm{ChE}^{u}$ ( $\mathrm{u}=$ usual) is found in about $95 \%$ of Caucasian populations. About $4 \%$ should be expected to be $\mathrm{ChE}^{\mathrm{u}} \mathrm{ChE}^{\mathrm{a}}$ (a = atypical); the atypical $\mathrm{ChE}$ has recently been shown to be an Asp-70 - > Gly mutation owing to a change of the actual $\mathrm{ChE}^{\mathrm{a}}$ codon from GAT to GGT. ${ }^{5}$ Within a Caucasian population one person in 100000 will be expected to be of ChE-1 genotype $\mathrm{ChE}^{\mathrm{s}} \mathrm{ChE}^{\mathrm{s}}$ (s = silent) without detectable ChE catalytic activity in plasma. Such people, who are found much more frequently among the Inuits of the north-western parts of Canada than among a general population (Dr Alison Dinwoodie, University of Alberta, Canada, personal communication), are healthy and without any increased risk of death unless exposed to suxamethonium to which they are extremely sensitive. ${ }^{4}$

Previous studies ${ }^{6-10}$ have analysed the well known, wide interindividual variation in plasma ChE activity in healthy subjects. Such variations, which are independent of electrophoretic heterogeneity, ${ }^{11}$ are statistically related to physiological factors such as body weight, height, and sex. ${ }^{710}$ Four of these studies $^{68-10}$ also describe substantial intraindividual variations that are independent of age, body weight, 
height, sex, and ChE-1 phenotype. ${ }^{10}$ The main problem in the interpretation of significant variations of plasma ChE activity (which is further influenced by a variety of other physiological and pathological conditions $\mathbf{4}^{4}$ is to decide whether a decrease in catalytic activity is caused by a reduced ChE substance concentration (for example, due to preanalytical errors, reduced ChE synthesis, or increased $\mathrm{ChE}$ degradation) or by a partial inhibition of the catalytic activity (for instance, due to absorbed organophosphorus insecticides).

This paper describes the inter and intraindividual variations in catalytic and immunoreactive ${ }^{12}$ plasma ChE activity in a group of employees of an organophosphorus factory. It also evaluates the variations by a multiple regression model that is appropriate for a healthy population group without occupational exposure to known $\mathrm{ChE}$ inhibitors. ${ }^{1013}$

\section{Materials and methods}

\section{SAMPLE}

During a period of 10 months (November 1987September 1988) heparin stabilised venous blood samples were taken, at intervals of four to six weeks, from 331 employees of an organophosphorus insecticide factory ( 319 men, 12 women) and 193 healthy volunteers (122 men, 71 women) not exposed to known $\mathrm{ChE}$ inhibitors. Plasma was separated from the blood cells within 24-30 hours after withdrawal and stored at $-20^{\circ} \mathrm{C}$. Detailed data concerning the 193 volunteers have already been published. ${ }^{1013}$

All employees of the organophosphorus insecticide factory (Cheminova, Lemvig, Denmark) were subdivided by the Health Service and the local safety committee into four groups according to their actual risk for exposure to toxic organophosphorus compounds as follows: group 1 (high risk for exposure); persons occupied with production of diethyl-phosphorochloridothionate; persons handling repairs and maintenance all over the factory: group 2 (medium risk for exposure); persons occupied with production of dimethyl-phosphorochloridothionate, parathion, methyl-parathion, malathion, pirimiphos, dimethoate, and p-nitrophenol; persons occupied with unspecified assistance, drawing, and handling of waste water; persons employed in quality control and development; persons occupied with laboratory routines: group 3 (low risk for exposure); persons occupied with production of dimethyl- and diethyldithiophosphoric acid; persons taking care of lubrication, fire control, etc.; engineers, supervisors, etc.: group 4 (negligible risk for exposure to toxic organophosphorus compounds); persons occupied with production of phosphoropentasulfide; persons within planning and management.

Age, body weight, height, previous liver disease, use of oral contraceptives, and any regular intake of drugs were recorded from information given by the Health Service. Of the 331 employees, 318 completed the full programme (six samples from each subject) and so did 131 of the 193 volunteers (table 1).

\section{ANALYTICAL METHODS}

Determination of plasma ChE activity was performed on a Cobas FARA centrifugal analyser by a continuous assay using $6 \mathrm{mmol} / \mathrm{l}$ butyrylthiocholine iodide (Merckotest 3337) as substrate. ${ }^{10}{ }^{11}$ Day to day reproducibility was assessed from parallel determinations of lyophilised quality control material (M + D Monitrol I-E and Monitrol II-E); coefficient of variation $(\mathrm{CV})=1.34 \%$ (mean $=4.38 \mathrm{kU} / \mathrm{l}, \mathrm{SD}=0.059 \mathrm{kU} / \mathrm{l}, \mathrm{n}=125)$ for $\operatorname{lot} \mathrm{No}$ PTD 108; CV $=1.92 \% \quad($ mean $=6.38 \mathrm{kU} / \mathrm{l}$, $\mathrm{SD}=0.123 \mathrm{kU} / \mathrm{l}, \mathrm{n}=44)$ for lot No LTD 209; and $\mathrm{CV}=1.36 \%($ mean $=6.51 \mathrm{kU} / 1, \mathrm{SD}=0.089 \mathrm{kU} / 1$, $\mathrm{n}=81$ ) for lot No LTD 210.

Phenotypes of ChE-1 (ChE types) were classified from inhibition of the catalytic activity by dibucaine and fluoride under reaction conditions as recommended by the Association of Clinical Pathologists. ${ }^{14}{ }^{15}$ Of the 316 employees of the organophosphorus insecticide factory, 18 men were classified as $\mathrm{ChE}^{u} \mathrm{ChE}^{\mathrm{a}}$. The remaining 298 were classified as $\mathrm{ChE}^{u} \mathrm{ChE}^{u}$. Of

Table 1 Population groups from which six blood samples were obtained. Risk group 1, high risk for exposure to organophosphorus insecticides; 2, medium risk; 3, low risk; 4, negligible risk; Reference group, subjects without occupational exposure to known ChE inhibitors

\begin{tabular}{|c|c|c|c|c|}
\hline Population group & No of subjects & $\begin{array}{l}\text { Mean body weight } \\
(\mathrm{kg}(S D))\end{array}$ & $\begin{array}{l}\text { Mean height } \\
(\mathrm{cm}(S D))\end{array}$ & $\begin{array}{l}\text { Mean age } \\
(y(S D))\end{array}$ \\
\hline $\begin{array}{l}\text { Employees } \\
\text { Risk group } 1 \\
\text { Risk group 2 } \\
\text { Men } \\
\text { Women } \\
\text { Risk group 3 } \\
\text { Risk group 4 }\end{array}$ & $\begin{array}{r}318 \\
75 \\
200 \\
188 \\
12 \\
29 \\
14\end{array}$ & $\begin{array}{l}79 \cdot 6(10 \cdot 8) \\
81 \cdot 3(9 \cdot 7) \\
78 \cdot 4(11 \cdot 0) \\
79 \cdot 2(10 \cdot 2) \\
66 \cdot 2(15 \cdot 4) \\
81 \cdot 8(12 \cdot 3) \\
82 \cdot 5(9 \cdot 9)\end{array}$ & $\begin{array}{l}176.5(6.5) \\
176.0(5 \cdot 8) \\
176.2(6.6) \\
176.8(6.0) \\
166.8(9.0) \\
179.2(7.9) \\
178.6(4.8)\end{array}$ & $\begin{array}{l}40 \cdot 2(9 \cdot 7) \\
40 \cdot 8(7 \cdot 5) \\
39 \cdot 3(10 \cdot 2) \\
39 \cdot 9(10 \cdot 0) \\
30 \cdot 1(8 \cdot 9) \\
41.9(9 \cdot 4) \\
46 \cdot 1(10 \cdot 5)\end{array}$ \\
\hline $\begin{array}{l}\text { Reference group } \\
\text { Men } \\
\text { Women }\end{array}$ & $\begin{array}{r}131 \\
75 \\
56\end{array}$ & $\begin{array}{l}71 \cdot 8(13 \cdot 0) \\
79 \cdot 5(9 \cdot 8) \\
61 \cdot 5(9 \cdot 0)\end{array}$ & $\begin{array}{l}173.0(8 \cdot 7) \\
178.3(6 \cdot 1) \\
165 \cdot 8(6 \cdot 0)\end{array}$ & $\begin{array}{l}39.0(9 \cdot 7) \\
38.9(9 \cdot 6) \\
39 \cdot 2(9 \cdot 8)\end{array}$ \\
\hline
\end{tabular}


Table 2 Mean (SD) ChE activity in each of six plasma samples (ChE-1-ChE-6) from 318 employees of an organophosphorus insecticide factory and in 131 healthy subjects without occupational exposure to known ChE inhibitors (reference group)

\begin{tabular}{|c|c|c|c|c|c|c|c|c|}
\hline $\begin{array}{l}\text { Population } \\
\text { group }\end{array}$ & $\begin{array}{l}\text { No of } \\
\text { subjects }\end{array}$ & $\begin{array}{l}C h E-1 \\
(k U / l(S D)\end{array}$ & $\begin{array}{l}C h E-2 \\
(k U / l(S D))\end{array}$ & $\begin{array}{l}C h E-3 \\
(k U / l(S D)\end{array}$ & $\begin{array}{l}C h E-4 \\
(k U / l(S D)\end{array}$ & $\begin{array}{l}C h E-5 \\
(k U / l(S D)\end{array}$ & $\begin{array}{l}C h E-6 \\
(k U / l(S D)\end{array}$ & $\begin{array}{l}\text { Standardised } C h E_{\text {mean }} \\
(k U / l(S D))\end{array}$ \\
\hline $\begin{array}{l}\text { Employees } \\
\text { Risk group } 1 \\
\text { Risk group } 2 \\
\text { Men } \\
\text { Women } \\
\text { Risk group } 3 \\
\text { Risk group } 4\end{array}$ & $\begin{array}{r}318 \\
75 \\
200 \\
188 \\
12 \\
29 \\
14\end{array}$ & $\begin{array}{l}8.78(1.79) \\
8.56(1.56) \\
8.94(1.88) \\
8.99(1.84) \\
8.08(2.43) \\
8.21(1.58) \\
8.93(1.71)\end{array}$ & $\begin{array}{l}8.83(1.81) \\
8.65(1.65) \\
8.96(1.88) \\
9.04(1.84) \\
7.86(2.21) \\
8.24(1.64) \\
9.09(1.86)\end{array}$ & $\begin{array}{l}8.78(1.85) \\
8.63(1.69) \\
8.92(1.93) \\
9.00(1.88) \\
7.57(2.29) \\
8.25(1.65) \\
8.81(1.79)\end{array}$ & $\begin{array}{l}8.78(1.81) \\
8.64(1.75) \\
8.89(1.84) \\
8.95(1.81) \\
7.99(2.13) \\
8.16(1.65) \\
9.18(1.94)\end{array}$ & $\begin{array}{l}8.76(1.89) \\
8.65(1.76) \\
8.88(1.95) \\
8.95(1.91) \\
7.75(2.29) \\
8.09(1.62) \\
8.97(1.99)\end{array}$ & $\begin{array}{l}8.57(1.85) \\
8.48(1.80) \\
8.66(1.91) \\
8.73(1.76) \\
7.67(2.47) \\
8.03(1.52) \\
8.89(1.83)\end{array}$ & $\begin{array}{l}8.21(1.64) \\
7.92(1.58) \\
8.39(1.66) \\
8.39(1.65) \\
8.31(1.88) \\
7.60(1.36) \\
8.40(1.78)\end{array}$ \\
\hline $\begin{array}{l}\text { Reference group } \\
\text { Men } \\
\text { Women }\end{array}$ & $\begin{array}{r}131 \\
75 \\
56\end{array}$ & $\begin{array}{l}8.26(1.92) \\
8.81(1.91) \\
7.53(1.68)\end{array}$ & $\begin{array}{l}8.15(1.85) \\
8.75(1.84) \\
7.34(1.54)\end{array}$ & $\begin{array}{l}7.92(1.79) \\
8.46(1.84) \\
7.20(1.46)\end{array}$ & $\begin{array}{l}8.03(1.85) \\
8.58(1.82) \\
7.29(1.62)\end{array}$ & $\begin{array}{l}8.00(1.83) \\
8.49(1.83) \\
7.33(1.63)\end{array}$ & $\begin{array}{l}8.17(1.93) \\
8.65(2.02) \\
7.53(1.61)\end{array}$ & $\begin{array}{l}8 \cdot 25(1.36) \\
8 \cdot 26(1.49) \\
8.25(1.18)\end{array}$ \\
\hline
\end{tabular}

the 131 volunteers of the reference group, seven were classified as $\mathrm{ChE}^{\mathrm{u}} \mathrm{ChE}^{\mathrm{a}}$, and the remaining 124 were classified as $\mathrm{ChE}^{\mathrm{u}} \mathrm{ChE}^{u}$.

Determination of immunoreactive ChE substance concentration was performed by an enzyme linked immunosorbent assay (ELISA) using polyclonal (rabbit) antihuman $\mathrm{ChE}$ antibodies combined with a highly specific monoclonal (mouse) antihuman $\mathrm{ChE}$ antibody and a peroxidase conjugated (rabbit) antibody against mouse immunoglobulins as signal carrier. $^{12}$ Day to day reproducibility was assessed from parallel determinations of lyophilised quality control material $(\mathbf{M}+\mathbf{D}$ Monitrol I-E and Monitrol II-E); $\quad C V=4.97 \% \quad$ (mean $=4.62 \mathrm{mg} / \mathrm{l}$, $\mathrm{SD}=0.23 \mathrm{mg} / \mathrm{l}, \mathrm{n}=73$ ) for lot No LTD 210; and $\mathrm{CV}=5.56 \%($ mean $=3.42 \mathrm{mg} / \mathrm{l}, \mathrm{SD}=0.19 \mathrm{mg} / \mathrm{l}$, $\mathrm{n}=83$ ) for lot No PTD 109.

\section{STATISTICS}

Results were evaluated from a multiple regression analysis, an analysis of variance covariance, and a repeated measure analysis of variance. ${ }^{10}{ }^{13}$ All calculations were performed on an IBM PC/AT using the SPSS/PC + software package (SPSS Inc, Chicago, II).

\section{Results}

CHOLINESTERASE ACTIVITY

Table 2 shows the total $\mathrm{ChE}$ activity in six plasma samples (ChE-1-ChE-6) from the 449 subjects (employees 318; reference group 131) who completed the full programme. It shows the well known wide interindividual variation that may conceal a treatment effect when comparing unmatched groups and subgroups. As described earlier ${ }^{10}$ this problem is partly overcome by comparing "standardised" $\mathrm{ChE}$ activities (from which the effect of varying body weight, height, sex, and ChE-1 phenotype is eliminated) instead of "raw" ChE activities. The right column of the table shows such standardised mean ChE activities (model: $\mathrm{ChE}_{\text {stand }}=\mathrm{ChE}_{\text {mean }}$ (weight-75) $\times 0.085+\left(\mathrm{ChE}_{\text {type }}-1\right) \times 2.77+$ (height-180) $\times 0.102+\left(\right.$ sex-1) $\times 1.09 ; \mathrm{ChE}_{\text {type }}$ : $\mathrm{ChE}^{\mathrm{u}} \mathrm{ChE}^{\mathrm{u}}=1, \mathrm{ChE}^{\mathrm{u}} \mathrm{ChE}^{\mathrm{a}}=2$; sex: $\operatorname{men}=1$, women $=2$; weight in $\mathrm{kg}$ and height in $\mathrm{cm}$ ). Standardised mean ChE activities of employees in risk group 3 were significantly lower than those of men in the reference group $(t=2.15,0.01<p<0.05)$, whereas standardised mean $\mathrm{ChE}$ activities of male employees in other risk groups did not differ from each other or from the men in the reference group. Female employees (risk group 2) showed the same standardised ChE activity as women in the reference group.

Table 3 shows maximum intraindividual variations (differences between a person's highest and lowest $\mathrm{ChE}$ as a percentage of the person's mean activity) and intraindividual variations expressed as individual SDs $(n=6)$. Like intraindividual variations in the reference group, ${ }^{10}$ intraindividual variations of the employees of the organophosphorus insecticide factory showed a skew to the right; average maximum variation was $12.6 \%$ (range: $3 \cdot 4$ $38.9 \%$ ) independently of the actual risk group and equal to that of the reference group (mean: $14.0 \%$, range: $3.0-41 \cdot 8 \%$ ). In 26 of the 318 employees, and in 23 of 131 referents the difference between highest and lowest $\mathrm{ChE}$ activity exceeded $20 \%$ of the mean

Table 3 Intraindividual variation of ChE activity $(n=6)$ in employees of an organophosphorus insecticide factory and in healthy subjects without occupational exposure to known ChE inhibitors (reference group)

\begin{tabular}{|c|c|c|c|}
\hline \multirow[b]{2}{*}{$\begin{array}{l}\text { Population } \\
\text { group }\end{array}$} & \multirow[b]{2}{*}{$\begin{array}{l}\text { No of } \\
\text { subjects }\end{array}$} & \multicolumn{2}{|l|}{ ChE activity } \\
\hline & & $\begin{array}{l}\text { Maximum variation } \\
\text { (mean and range) }\end{array}$ & $\begin{array}{l}\text { Individual } S D \\
\text { range }(k U / l)\end{array}$ \\
\hline $\begin{array}{l}\text { Employees } \\
\text { Risk group } 1 \\
\text { Risk group } 2 \\
\text { Risk group } 3 \\
\text { Risk group } 4\end{array}$ & $\begin{array}{r}318 \\
75 \\
200 \\
29 \\
14\end{array}$ & $\begin{array}{l}12.6(3.4-38.9) \\
12 \cdot 7(4 \cdot 3-32 \cdot 0) \\
12.9(3.4-38.9) \\
10.9(3.4-21.5) \\
11.3(3.7-18.6)\end{array}$ & $\begin{array}{l}0.11-1.02 \\
0.12-0.90 \\
0.11-1.02 \\
0.15-0.63 \\
0.18-0.62\end{array}$ \\
\hline Reference group & 131 & $14.0(3.0-41 \cdot 8)$ & $0 \cdot 10-1 \cdot 12$ \\
\hline
\end{tabular}


Table 4 Immunoreactive ChE substance concentration (mean of six samples) in 316 employees of an organophosphorus insecticide factory and in 94 healthy subjects without occupational exposure to known $C h E$ inhibitors (reference group)

\begin{tabular}{|c|c|c|c|}
\hline $\begin{array}{l}\text { Population } \\
\text { group }\end{array}$ & $\begin{array}{l}\text { No of } \\
\text { subjects }\end{array}$ & $\begin{array}{l}\text { ChE substance } \\
\text { concentration } \\
\text { (mean } \mathrm{mg} / \mathrm{l}(S D))\end{array}$ & $\begin{array}{l}\text { Standardised } \\
\text { ChE substance conc } \\
\text { (mean mg/l (SD)) }\end{array}$ \\
\hline $\begin{array}{l}\text { Employees } \\
\text { Risk group } 1 \\
\text { Risk group } 2 \\
\text { Men } \\
\text { Women } \\
\text { Risk group } 3 \\
\text { Risk group } 4\end{array}$ & $\begin{array}{r}316 \\
74 \\
199 \\
187 \\
12 \\
29 \\
14\end{array}$ & $\begin{array}{l}5.47(1.14) \\
5.42(1.06) \\
5.53(1.19) \\
5.58(1.16) \\
4.77(1.36) \\
5.12(0.99) \\
5.62(1.09)\end{array}$ & $\begin{array}{l}5.13(1.09) \\
4.96(1.06) \\
5.23(1.11) \\
5.23(1.11) \\
5.20(1.16) \\
4.78(0.91) \\
5.26(1.13)\end{array}$ \\
\hline $\begin{array}{l}\text { Reference group } \\
\text { Men } \\
\text { Women }\end{array}$ & $\begin{array}{l}94 \\
43 \\
51\end{array}$ & $\begin{array}{l}5 \cdot 01(1 \cdot 11) \\
5 \cdot 42(1 \cdot 23) \\
4.66(0.88)\end{array}$ & $\begin{array}{l}5.28(0.91) \\
5 \cdot 28(1.09) \\
5 \cdot 28(0.74)\end{array}$ \\
\hline
\end{tabular}

activity. In four of the employees and in three of the referents the maximum intraindividual variation exceeded $30 \%$. The maximum intraindividual variation (expressed relative to the mean activity) was independent of $\mathrm{ChE}$ activity. ${ }^{10}$

A quantitative estimate of the intraindividual variance of the 318 employees was obtained from a repeated measures analysis of variance, which also gives a quantitative estimate of the influence by risk group on the intraindividual variation of $\mathrm{ChE}$ activity from one sample to another (second sample $v$ first sample, third sample $v$ first and second, fourth sample $v$ first, second, and third, etc). The repeated measures analysis of variance showed an average $S_{\text {intra }}$ of $0.43 \mathrm{kU} / 1$ without influence of actual risk group $(F=1.05, p>0 \cdot 10)$. In the same way, the average $S_{\text {intra }}$ of the reference group was $0.44 \mathrm{kU} / 1$.

\section{CHOLINESTERASE SUBSTANCE CONCENTRATION}

Of the 449 subjects who completed the full programme, immunoreactive ChE substance concentrations were measured in 316 of the 318 employees, and in 94 of the 131 subjects of the reference group. Table 4 shows the immunoreactive ChE substance concentrations of all 410 subjects studied. Like ChE activities, ChE substance concentrations are influenced by body weight, height, sex, and ChE-1 phenotype; ; $^{13}$ therefore, "standardised" mean $\mathrm{ChE}$ substance concentrations (model: $\mathrm{ChE}_{\text {stand }}$ $=\mathrm{ChE}_{\text {mean }}-$ (weight-75) $\times 0.048+\left(\mathrm{ChE}_{\text {type }}-\right.$ 1) $\times 1.10+($ height-180) $\times 0.064+($ sex-1) $\times$ $0.85)$ are preferable when comparing groups and subgroups. Like standardised ChE activity, standardised ChE substance concentration of employees in risk group 3 differed significantly $(t=2 \cdot 12$, $0.01<p<0.05)$ from that of men in the reference group; no other male groups differed from each other. Female employees showed the same standardised ChE substance concentration as women in the reference group.
Table 5 shows the maximum intraindividual variations and intraindividual variations expressed as individual $\mathrm{SD}(\mathrm{n}=6)$. As in the reference group, ${ }^{13}$ the distribution of intraindividual variations of the employees of the organophosphorus insecticide factory was skewed to the right. Average maximum variation was $18 \cdot 7 \%$ (range: $3-43 \%$ ), independent of actual risk group, and similar to that of the reference group (mean: $20 \%$, range: $6-43 \%$ ). Within the 316 employees, a repeated measures analysis of variance showed an average $S_{\text {intra }}$ of $0.41 \mathrm{mg} / 1$ (reference group: $\mathrm{SD}_{\text {intra }}=0.44 \mathrm{mg} / \mathrm{l}$ ).

\section{Discussion}

The use of plasma ChE activity measurements for biological monitoring should not be confused with relating the enzymatic activity to clinical or toxicological effects. Earlier systematic studies of $\mathrm{ChE}$ after exposure to the toxic organophosphorus compound DFP (diisopropylfluorophosphate) showed up to $95 \%$ reduction of plasma $\mathrm{ChE}$ activity after parenteral administration of $0.5-3.0 \mathrm{mg} \cdot{ }^{16-18}$ No close relation between toxic symptoms and changes in plasma ChE activities were seen. Although distinct organophosphorus insecticides inhibit plasma $\mathrm{ChE}$ to a varying extent, ${ }^{1}$ and although plasma $\mathrm{ChE}$ differs in amino acid sequence from the target enzyme for organophosphorus insecticides (acetylcholinesterase EC 3.1.1.7), the use of plasma ChE activity for monitoring exposure to organophosphorus insecticides offers great advantages compared with erythrocyte acetylcholinesterase, which (contrary to plasma $\mathrm{ChE}$ ) appears quite instable, even when stored at $-20^{\circ} \mathrm{C}$ (A Brock, unpublished observations).

When comparing plasma ChE activity in unmatched groups or subgroups, influence by factors other than organophosphorus inhibitors has to be considered. The effects by ChE-1 phenotype and sex are well known, ${ }^{4714}$ but also (as in other liver synthesised plasma enzymes ${ }^{19}$ ) varying body weight and height has appeared to affect the interindividual variation of plasma ChE activity ${ }^{10}$ as well as plasma ChE substance concentration. ${ }^{13}$ Even when considering all

Table 5 Intraindividual variation of ChE substance concentration $(n=6)$ in employees of an organophosphorus insecticide factory, and in healthy subjects without occupational exposure to known ChE inhibitors (reference group)

\begin{tabular}{lcll}
\hline $\begin{array}{l}\text { Population } \\
\text { group }\end{array}$ & $\begin{array}{l}\text { No of } \\
\text { subjects }\end{array}$ & $\begin{array}{l}\text { Maximum variation } \\
\text { (mean and range) }\end{array}$ & $\begin{array}{l}\text { Individual SD } \\
\text { range }(\text { mg/l) }\end{array}$ \\
\hline Employees & 316 & $18 \cdot 7(3 \cdot 2-43 \cdot 0)$ & $0 \cdot 06-1 \cdot 20$ \\
Risk group 1 & 74 & $17 \cdot 1(5 \cdot 4-38 \cdot 0)$ & $0 \cdot 11-0 \cdot 89$ \\
Risk group 2 & 199 & $19 \cdot 4(3 \cdot 2-43 \cdot 0)$ & $0 \cdot 06-1 \cdot 20$ \\
Risk group 3 & 29 & $18 \cdot 2(10 \cdot 4-29 \cdot 7)$ & $0 \cdot 18-0 \cdot 69$ \\
Risk group 4 & 14 & $18 \cdot 2(7 \cdot 8-28 \cdot 8)$ & $0 \cdot 18-0 \cdot 66$ \\
Reference group & 94 & $20 \cdot 1(6 \cdot 4-43 \cdot 2)$ & $0 \cdot 11-1 \cdot 35$ \\
\hline
\end{tabular}


Table 6 ChE specific catalytic activity (mean of six samples) in 316 employees of an organophosphorus insecticide factory and in healthy subjects without occupational exposure to known ChE inhibitors (reference group)

\begin{tabular}{lll}
\hline Population group & $\begin{array}{l}\text { No of } \\
\text { subjects }\end{array}$ & $\begin{array}{l}\text { ChE specific activity } \\
\text { (mean kU/mg }(S D) \text { ) }\end{array}$ \\
\hline Phenotype ChE ${ }^{u} \mathrm{ChE}^{u}$ & 387 & $1.61(0.05)$ \\
Employees: & 67 & $1.62(0.05)$ \\
$\quad$ Risk group 1 & 190 & $1.62(0.05)$ \\
Risk group 2 & 28 & $1.61(0.05)$ \\
Risk group 3 & 13 & $1.62(0.04)$ \\
Risk group 4 & 89 & $1.59(0.05)$ \\
Reference group & 23 & $1.30(0.07)$ \\
Phenotype ChE ChE & & \\
Employees: & 7 & $1.33(0.03)$ \\
$\quad$ Risk group 1 & 9 & $1.32(0.04)$ \\
Risk group 2 & 1 & $1.38(-)$ \\
Risk group 3 & 1 & $1.33(-)$ \\
Risk group 4 & 5 & $1.22(0.09)$ \\
Reference group & & \\
\hline
\end{tabular}

these factors, however, unjustified conclusions may be drawn. In the present paper standardised $\mathrm{ChE}$ activities of employees in one risk group (group 3, low risk for exposure to organophosphorus insecticides) were significantly lower than in other groups and subgroups. To examine the question "Were workers in risk group 3 subjected to exposure to $\mathrm{ChE}$ inhibitors?" ChE specific catalytic activities (ChE activities relative to $\mathrm{ChE}$ substance concentrations) of all 410 subjects were compared. Table 6 shows ChE specific catalytic activities by ChE-1 phenotype, which is the only physiological factor known to influence this quantity. ${ }^{13}$ The specific catalytic activity of subjects in risk group 3 equals those of the other groups and subgroups. As inhibition of ChE activity by organophosphorus insecticides (phosphorylation of the catalytic active site ${ }^{1}$ ) does not influence the plasma turnover rate, ${ }^{4}$ it was concluded that risk group 3 was not subjected to disproportionate exposure.

In health surveillance programmes, changes in plasma ChE activity are used to indicate occupational exposure of the person to organophosphorus insecticides. In accordance with earlier studies ${ }^{689}$ (each based on 22-24 subjects) the present study, including

Table 7 Intraindividual variation of $C h E$ specific activity $(n=6)$ in employees of an organophosphorus insecticide factory and in healthy subjects without occupational exposure to known ChE inhibitors (referenced group)

\begin{tabular}{lrll}
\hline $\begin{array}{l}\text { Population } \\
\text { group }\end{array}$ & $\begin{array}{l}\text { No of } \\
\text { subjects }\end{array}$ & $\begin{array}{l}\text { Maximum variation } \\
\text { (mean and range) }\end{array}$ & $\begin{array}{l}\text { Individual SD } \\
\text { range }(k U / m g)\end{array}$ \\
\hline Employees & 316 & $15 \cdot 8(3 \cdot 2-30 \cdot 8)$ & $0 \cdot 02-0 \cdot 18$ \\
Risk group 1 & 74 & $14 \cdot 3(4 \cdot 0-30 \cdot 8)$ & $0 \cdot 02-0 \cdot 18$ \\
Risk group 2 & 199 & $16 \cdot 0(3 \cdot 6-29 \cdot 7)$ & $0 \cdot 02-0 \cdot 17$ \\
Risk group 3 & 29 & $16 \cdot 3(7 \cdot 8-27 \cdot 2)$ & $0 \cdot 05-0 \cdot 16$ \\
Risk group 4 & 14 & $19 \cdot 1(5 \cdot 8-28 \cdot 4)$ & $0 \cdot 03-0 \cdot 16$ \\
Reference group & 94 & $17 \cdot 5(5 \cdot 7-37 \cdot 1)$ & $0 \cdot 03-0 \cdot 21$ \\
\hline
\end{tabular}

a more detailed analysis of the reference group, ${ }^{10}$ shows substantial intraindividual variations of plasma ChE activity even in healthy unexposed persons. The magnitude of such normal variations are crucial in diagnostic decision making ${ }^{20}$ and for defining appropriate analytical goals. ${ }^{2122}$ Analytical imprecisions of the actual $\mathrm{ChE}$ activity assay are immaterial compared with the biological intraindividual variations. ${ }^{10}$ Hence, analytical improvements will not significantly reduce the observed intraindividual variations, and strategies of health surveillance programmes are forced to accept such large variations in plasma $\mathrm{ChE}$ activity. According to the British Health and Safety Executive ${ }^{23}$ persons should be medically examined "if, during routine monitoring, plasma $\mathrm{ChE}$ activity has been shown to have fallen by more than $30 \%$ of preexposure levels." This strategy, which corresponds with the intraindividual variation of $\mathrm{ChE}$ activity found in the present study (only four of the 318 employees showed intraindividual variations higher than $30 \%$ ), might be replaced by a strategy based on variations of ChE specific activity that within healthy persons exhibit insignificant biological intraindividual variations. ${ }^{13}$ Unfortunately, the actual analytical imprecision of the ELISA assay for ChE substance concentrations $(\mathrm{CV}=5-5.5 \%)$ so far eliminates most of the theoretical advantages of a strategy based on this quantity (table 7).

Until a real improvement in analytical precision of the $\mathrm{ChE}$ substance assay is achieved, $\mathrm{ChE}$ specific catalytic activity will be of limited value when dealing with minor intraindividual changes of $\mathrm{ChE}$ activity. When comparing groups and subgroups within a health surveillance programme and when unexpected large intraindividual variations in plasma ChE activity are to be interpreted, measurement of plasma $\mathrm{ChE}$ specific activity must be considered as a rational diagnostic tool.

I express my gratitude to Professor Rud Keiding of the University of Aarhus for inspiring discussions and encouraging support. All members of the participating staff at the Department of Clinical Chemistry, Randers Centralsygehus, and the local Health Service, Cheminova, are acknowledged for their most professional and enthusiastic efforts. The Hormone Department, Statens Seruminstitut, Copenhagen (head: B Nørgaard-Pedersen) is acknowledged for supplying the monoclonal antibody HAH 2-1 against human ChE. The study was financially supported by Aarhus University Research Foundation.

1 Eto M. Organophosphorus pesticides: organic and biological chemistry. Cleveland, Ohio: CRC Press, 1976:123-230.

2 Fraser CG. The application of theoretical goals based on 
biological variation data in proficiency testing. Arch Pathol Lab Med 1988;112:404-15.

3 Lockridge O, Bartels CF, Vaughan TA, Wong CK, Norton SE, Johnson LL. Complete amino acid sequence of human serum cholinesterase. J Biol Chem 1987;262:549-57.

4 Whittaker M. Cholinesterase. Basel: Karger, 1986:1-132.

5 McGuire MC, Nogueira CP, Bartels CF, et al. Identification of the structural mutation responsible for the dibucaine-resistant (atypical) variant form of human serum cholinesterase. Proc Natl Acad Sci 1989;86:953-7.

6 Sidell FR, Kaminskis A. Temporal intrapersonal physiological variability of cholinesterase activity in human plasma and erythrocytes. Clin Chem 1975;21:1961-3.

7 Lepage L, Schiele F, Gueguen R, Siest G. Total cholinesterase in Plasma: Biological variations and reference limits. Clin Chem 1985;31:546-50.

8 Moses GC, Tuckerman JF, Henderson AR. Biological variance of cholinesterase and $5^{\prime}$-nucleotidase in serum of healthy persons. Clin Chem 1986;32:175-7.

9 Hölzel WGE. Intra-individual variation of analytes in serum from patients with chronic liver diseases. Clin Chem 1987;33:1133-6.

10 Brock A, Brock V. Plasma cholinesterase activity in a healthy population group without occupational exposure to known cholinesterase inhibitors: Relative influence of some factors related to normal inter- and intra-individual variations. Scand $J$ Clin Lab Invest 1990;50:401-8.

11 Brock A. Additional electrophoretic components of cholinesterase in Plasma: a phenomenon of no importance to the total plasma cholinesterase activity. $J$ Clin Chem Clin Biochem 1989;27:429-31.

12 Brock A, Mortensen V, Loft AGR, Nørgaard-Pedersen B. Enzyme Immunoassay of human cholinesterase (EC 3.1.1.8): Immunoreactive substance concentration compared to catalytic activity concentration in randomly selected serum samples from healthy individuals. J Clin Chem Clin Biochem 1990;28:221-4.
13 Brock A. Immunoreactive plasma cholinesterase (EC 3.1.1.8) substance concentration, compared with cholinesterase activity concentration and albumin: Inter- and intraindividual variations in a healthy population group. $J$ Clin Chem Clin Biochem 1990;28:851-6.

14 Silk E, King J, Whittaker M. Assay of cholinesterase in clinical chemistry. Ann Clin Biochem 1979;16:57-75.

15 Brock A. Plasma cholinesterase genetic variants phenotyped using a Cobas-Fara centrifugal analyser. J Clin Chem Clin Biochem 1988;26:873-5.

16 Grob D, Lilienthal JL, Harvey AM, Jones BF. The administration of di-isopropyl fluorophosphate (DFP) to man. Bulletin of the Johns Hopkins Hospital 1947;81:217-44.

17 Verberk $M M$. Incipient cholinesterase inhibition in volunteers ingesting monocrotophos or mevinphos for one month. Toxicol Appl Pharmacol 1977;42:345-50.

18 Munkner T, Matzke J, Videbæk A. Cholinesterase activity of human plasma after intramuscular diisopropyl fluorophosphonate (DFP). Acta Pharmacol Toxicol 1961;18:170-4.

19 Robinson D, Whitehead TP. Effect of body mass and other factors on serum liver enzyme levels in men attending for well population screening. Ann Clin Biochem 1989;26:393-400.

20 Harris EK, Yasaka T. On the calculation of a "reference change" for comparing two consecutive measurements. Clin Chem 1983;29:25-30.

21 Fraser CG. Desirable performance standards for clinical chemistry tests. Adv Clin Chem 1983;23:299-339.

22 Fraser CG. The application of theoretical goals based on biological variation data in proficiency testing. Arch Pathol Lab Med 1988;112:404-15.

23 Guidance Note MS 17. Health surveillance of workers exposed to organo-phosphorus pesticides. Sheffield: Health and Safety Executive Library and Information Services, 1987:1-4.

Accepted 26 November 1990 